\title{
Tulip Time and the Invention of a New Dutch American Ethnic Identity
}

\section{Michael Douma}

In the 1930s, the Dutch American immigrant community of Holland, Michigan, underwent a cultural reawakening through its Dutch heritage Tulip Time festival. Tulip Time began in 1929 as a city beautification project. It was essentially a horticultural festival featuring 100,000 tulips imported from the Netherlands. Each year it added new cultural features such as a Dutch market, Dutch-language church services, Dutch cultural parades, and regular performances by klompen (wooden shoe) dancers traditionally dressed in the most colorful Dutch costumes, so that it continued to grow in popularity. By the mid1930 s, over a half million visitors per year came to see the tulips and partake in the traditions of old Holland. ${ }^{1}$ But while the festival and the new generations of Dutch Americans that organized it attempted to recreate and promote authentic Dutch culture, the portrayals of the Dutch, like the braided blonde-haired klompen dancers pushing brooms to scrub the streets, engendered stereotypes and caricatures that hardly represented the Dutch Americans of the past. The festival's "Dutchness," wrote Dutch American author Arnold Mulder, "was less a matter of nationality and blood than of an American flair for effective community publicity." According to historian Suzanne Sinke, Tulip Time in later years was neither completely Dutch, nor wholly American, but rather was a peculiar hybrid, born and continuing to be reinterpreted in a dialectical process between cultures and shaped by an all too apparent subservience to the demands of commercialism and consumerism. ${ }^{3}$ 
Tulip Time was one of many ethnic movements originating in early twentieth-century America that were led by descendants of immigrants who sought to reconnect with their European heritage. In 1937, speaking to a Swedish American historical society, historian Marcus Lee Hansen explained that there was an "almost universal" phenomenon among immigrant groups in the United States, in which the third generation seeks to remember what the second forgot. The alienated second generation, he argued, feels caught between cultures and has little patience for its parents' ways and little interest in telling their stories. But third-generation immigrants speak fluent vernacular, feel at home in the land of their birth, and consider recent immigrants to be of the inassimilable hordes. To explain and justify their own group's rise from poor immigrants to respectable citizens, third-generation immigrants research history and genealogy and study language, and through it all, develop pride in their heritage. Like the progressive Chicago School, epitomized in Thomas and Znaniecki's The Polish Peasant in Europe and America (1996), Hansen proposed inevitability in history. "Hansen's Law," this broad and Hegelian account of generational change as the engine of ethnic development, became a popular tool for explaining the past. ${ }^{4}$ In Holland's Tulip Time, Hansen would have noticed the telltale signs of a third generation's interest taken to an extreme.

But many historians have found Hansen's explanation of ethnic change too simple, and they generally reject such malleable definitions as his formulation of an acting generation. ${ }^{5}$ Stronger explanations of the changing identities of ethnic groups in America consider the role of individuals within a national or transnational context. Studies of ethnic tourism in the United States, for example, show how immigrants at various stages of assimilation expressed publicly their ethnicity and thereby refashioned new American forms of identities. Most of these studies, however, cover only the post-World War II years. ${ }^{6}$ Standard works such as Dinnerstein and Reimer's Ethnic American: A History of Immigration (2009) reinforce our knowledge that the ethnic revival of the 1970s led to a proliferation of ethnic parades and heritage festivals. ${ }^{7}$ But ethnic pageantry already had widespread social and economic consequences in the early twentieth century. Minor ethnic ceremonies and commemorations became major parades and festivals with the arrival of car culture. Indeed, the increased mobility of the automobile age led to greater interaction between ethnic groups and "outsiders," and it fueled the search for uniqueness and authenticity in a growing mass society. An ethnic tourism industry sprouted to meet the new demand.

In the 1930s, Holland, Michigan's, Tulip Time produced and marketed new concepts of "Dutchness," or new forms of identity for Dutch Americans. In a recent scholarly investigation of the traditions of Tulip Time, Deborah Che argued that the festival is "a celebration of diasporic Dutch heritage in Michigan, not the heritage of the Netherlands." ${ }^{\prime \prime}$ According to Che, Dutch America as a diasporic community developed Tulip Time to help hold on to a sense of distinctiveness in the face of outside pressures, that is, Americanization. Although unaware of Suzanne Sinke's earlier work, Che saw in the festival a 


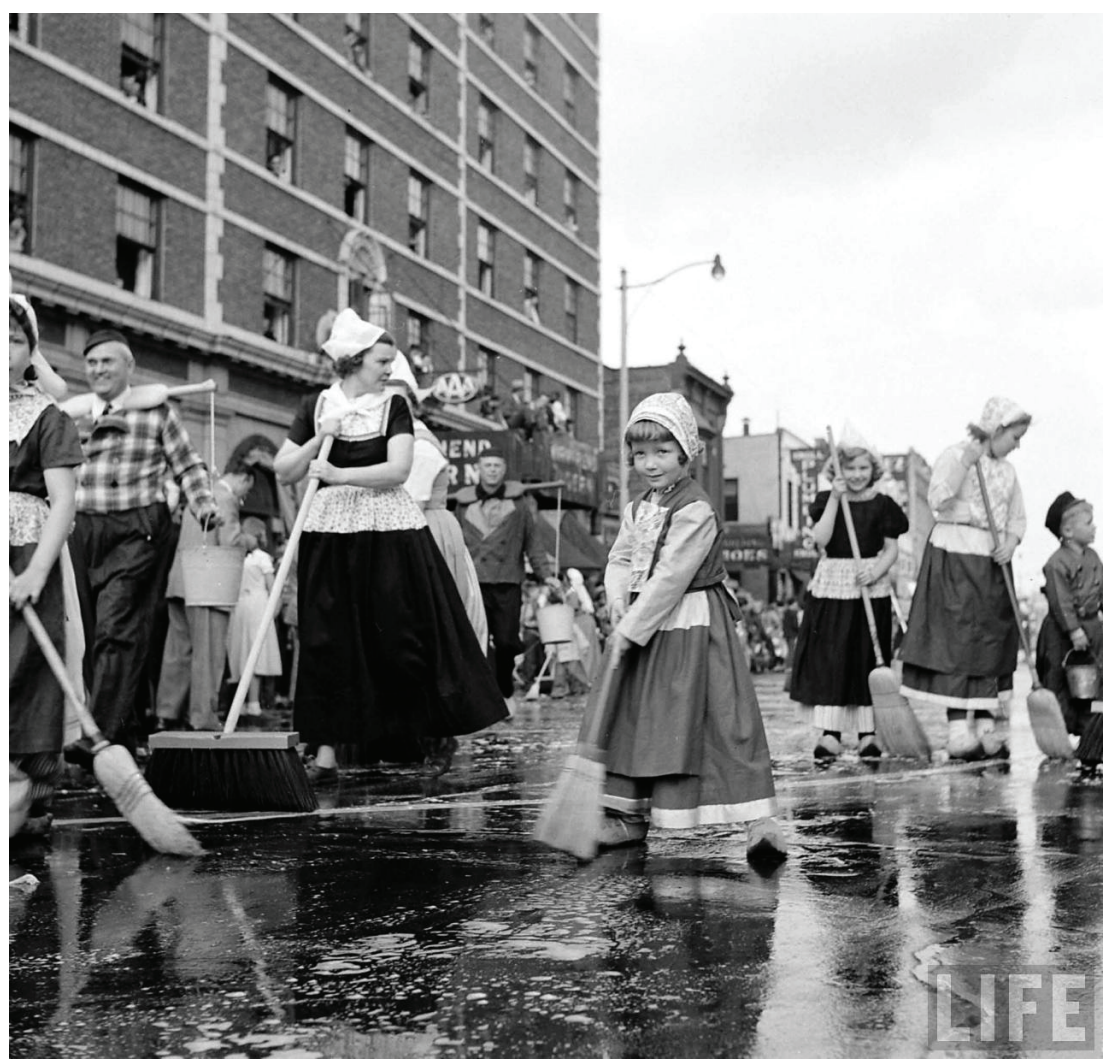

Figure 1: Dutch-dressed children have played an important role in the festival's image. Photographs of Holland, Michigan's Tulip Time parade taken for Life Magazine, May, 1950. Photograph by George Skadding.

similar hybridization of Dutch and American themes. But she also added to the dialectic of cultures the idea of "emergent authenticity," stating that inauthentic Dutch traditions became or "emerged" as authentic Dutch American traditions through their perpetual application. Thus, Che justified Tulip Time traditions as locally authentic in the sense that they originated in Holland, Michigan, in the 1930s and played an important role in defining Dutch American culture in the latter half of the twentieth century. ${ }^{9}$

While Che's "emergent authenticity" thesis is compelling, she was mistaken to see the festival, at least in its early decades, as a celebration of Dutch American heritage. The festival was originally an attempt to promote foreign Dutch culture, a "revival of old Netherlands customs and traditions," wrote 1930s amateur historian Peter Moerdyke. ${ }^{10}$ Its primary purpose was not, however, to relate the immigration experience or glorify the deeds of Dutch American pioneer leaders such as Albertus Van Raalte or Hendrik Scholte, nor did it 
much express the Calvinistic creed central to the Dutch American spirit. The beginning of Tulip Time signaled a coming-of-age in the assimilation process of Dutch Americans. Unlike German American festivities, which dated back to the mid-nineteenth century, Tulip Time was based neither on tradition nor precedent - much had to be improvised. Stereotypical images of the Dutchtheir supposedly traditional costumes, their wooden shoes, windmills, and of course their ubiquitous tulips - combined to reinvent and promote a new view of Dutch America. Consequently, Tulip Time became an unintentional caricature of Dutch culture and an affirmation of how Americanized the Dutch Americans had actually become.

An investigation into the role of assimilation, traditions, and ethnicity in Tulip Time adds to the growing literature from scholars who have come to see traditions and rituals in ethnic festivals as not only a form of fun and expression, but also a powerful force in shaping ethnic identity. In an article in Werner Sollors's The Invention of Ethnicity (1989), Kathleen Neils Conzen argued that German American festive culture, with its invented rituals, played a central role in establishing communitas, unifying multidenominational German Americans, and defining an immigrant culture under a set of common traditions. ${ }^{11}$ April Schultz sees Norwegian American festive culture as a process of cultural change and a "negotiation among various forces in the community," forces such as romanticism, nationalism, and a reaction to World War I Americanization drives. ${ }^{12}$ Case studies of individual communities have illustrated similar themes. Lindsborg, Kansas, for example, drew on Swedish folk traditions to establish a sense of distinctiveness and to create a meaningful sense of civic community that went beyond ethnic boundaries. ${ }^{13}$ Lon Kurashige, in an investigation of the Japanese Nisei week celebrations in Los Angeles, also identified tradition's role as a means of "promoting and policing group boundaries." 14 Even the dedication of his book illustrates the process of cultural change when Kurashige thanks his parents for "teaching me about my ethnicity and then letting me figure it out for myself., ${ }^{15}$ Kurashige seems to be making a point that all people, to an extent, must "figure out" their ethnicity. Learning about one's ethnicity is a continuing and never-ending process in the search for self-identity.

How did the Dutch Americans "figure out" their ethnicity through Tulip Time? I argue that the essential force behind the birth and development of Tulip Time was tension between immigrants at different levels of assimilation and their ideas of what it meant to be Dutch. It is precisely the lack of consensus between competing interpretations of ethnic identity and the lack of clear generational boundaries that leads to change over time and the emergence of new individual and group identities. The creation of community, the feeling of a common purpose, as Conzen, Schultz, and others have described, was also a goal of Tulip Time organizers, despite their competing visions. Tulip Time was initiated and promoted by Americans with no Dutch blood at all and by more fully assimilated Dutch Americans, whom Hansen would have identified as members of the third and fourth generation. Dutch Americans who were more 
familiar with Dutch culture but shunned it in order to better assimilate thought the festival a poor and rather absurd representation of the Dutch. Immigrants who had been born in the Netherlands, although recognizing little of their home culture in the festival, often accepted the mischaracterizations as benign, while hoping to capitalize on their own status as "truly Dutch." The early development of Tulip Time depended on the competition among no fewer than three types of Dutch Americans: those who promoted, those who criticized, and those who capitalized on the promotion of Dutch culture.

This article, therefore, presents an argument for the evolution of immigrant ethnic identities based on the competition of ideas, with forces both endogenous and exogenous to the immigrant community. In this instance, Tulip Time was a forum for competing images of Dutch ethnic identity. The festival also became an essential contributor to the city of Holland's financial well-being during the Great Depression. As city leaders and Tulip Time organizers developed the festival, and as Dutch Americans chose to participate or contribute, they identified essential elements of a new Dutch American identity, always with an eye for community promotion. Players in the festival sought their own financial or psychological benefit. Tulip Time was in this way a market for ethnicity, and the spread of this festival to other Dutch American communities shows that it was a successful ethnic product.

Tulip Time was born in a tumultuous period when the forces of Americanization, modernism, and secularism shook the foundations of Dutch America, a scattered but networked community of primarily Protestant Dutch immigrants in the American Midwest. ${ }^{16}$ When the thirty-two-year-old Dutch historian Jacob Van Hinte came to the United States for six weeks in 1921 to research the American Dutch, he discovered firsthand the forces shaping their communities. With his stay in the United States limited to a mere six weeks, the determined Van Hinte raced from one Dutch settlement to the next, scouring archives, conducting interviews, and taking notes along the way. After returning to the Netherlands, it took him seven years to complete the dissertation that became his published masterpiece in 1928. The work was nearly comprehensive, since Van Hinte, a social geographer by training, worked with the rigorous scientific methodology of professional European historians epitomized in Leopold von Ranke, the nineteenth-century German historian who would, as the proverb goes, cross the ocean to verify a comma. ${ }^{17}$

While Van Hinte was strongly nationalistic (for his own Netherlands), he believed Americanization of the Dutch immigrants was in their best interest. Yet, he feared the threat of Americanization to the Dutch immigrants' religious life. Americanization, he wrote, is "naturally most strongly expressed by the younger generation and is accompanied by an equally strong secularism." It was the "degenerate" behavior of the youth, specifically their desire for playing cards and dancing, and for short skirts and bobbed hair, that he found most troubling. Nevertheless, Van Hinte was well aware that the culture was changing and that it was of no use to promote old Dutch traditions, which in many cases 
the youth could no longer properly understand. In discussing Dutch habits still alive in the Midwestern settlements, Van Hinte noted that "in a few instances one gets the impression that a custom, which had practically died out in the Old Country, was revived in America, or at least kept alive ... in an exaggerated and even in a wild, disorderly form." 18

In tracing the history of the Dutch Americans, Van Hinte recognized a loss of belonging in the form of a growing alienation experienced by later generations. As he explained it, the first wave of Dutch immigrants consisted of religious separatists - primarily orthodox Calvinists - who fled official persecution in the Netherlands. It was the hope of the leader of the Holland colony, Albertus C. Van Raalte, that the immigrants would build a city on a hill, a frontier Christian community held together by religion and family. But the local orthodoxy in Holland, Michigan, and other Dutch American communities met a growing resistance in the post-Civil War period. For one reason, religious separatists were a minority in the new waves of immigrants from the Netherlands. In addition, their children, trained by Yankee schoolteachers and experiencing increased contact with native-born Americans, questioned the strict Calvinism and cultural presuppositions of the early settlers. Van Hinte identified the cultural and spiritual components of the struggle that continued in the minds of many immigrants throughout the Dutch-American Midwest.

\begin{abstract}
... it happened that some educated Dutch-Americans revealed their deepest feelings to me and confessed that they actually did not feel at home in America even though they had lived here since their childhood and admitted that they "had it very good here." They felt it was impossible for them to become wrapped up in Yankee life, but they could not return to the Netherlands and to its spiritual atmosphere that they felt they needed. They felt therefore unbalanced, without a real identity, for they were no longer Netherlanders and actually they were not American either. ${ }^{19}$
\end{abstract}

In Van Hinte's eyes, Dutch Americans were longing for identity but did not know where to find it. For young Dutch Americans, the "old country" was full of "old folks." After all, it seemed that most correspondence from the Netherlands was written by old aunts and uncles, and their letters tended more often than not to discuss the illnesses and deaths of elderly relatives. The Netherlands, one could lament, was an economically backward, premodern and aged country, and the younger generations seemed understandably reluctant to claim that as a part of their cultural identity. ${ }^{20}$

Tulip Time appealed to the younger generations. The festival presented an alternative view of Dutch ethnicity, devoid of the memories of struggle and the paradoxes of ethnic identification in America. However, for some Dutch Americans, the new portrayal of "Dutchness" was an unwelcome development. The 
attempted "ethnological connection with the people of the Netherlands," wrote Arnold Mulder, "was almost as stagey as the festival itself." ${ }^{\text {21 }}$ Mulder described the festival as a "reflection of the innate romanticism concealed beneath the shell of Dutch practicality" and as "evidence of a continuing pride of race." 22 As a second-generation immigrant, Mulder spent much energy and a significant portion of his professional career promoting assimilation and reform among the Dutch Americans. In his view, Tulip Time was a setback in these efforts, a regression from rational modernism to emotional primitivism. Other local Dutch Americans shared Mulder's assessment. Bill Plumert, who had migrated from the Netherlands in 1923, described the festival in 1946, in Dutch, as "Allemaal reclame" (all advertisements). He complained about the "wooden shoes and Volendam costumes and yokes with buckets of water to scrub the streets. And from Hollywood come the film stars to be photographed with a broom in their hands. It is nice to see, but it is all publicity-nonsense." Plumert punctuated his assessment in English, saying, "I don't like it." ${ }^{23}$ Nevertheless, Tulip Time became a popular and important forum for expressing solidarity and common identity.

Despite the competing interpretations of the Dutch on display, the citizens of Holland, Michigan, were widely supportive of the general presentation. In a quite literal way, the seeds of Tulip Time were sown in the home-front efforts of the First World War. In the summer of 1918, high school biology teacher Lida Rogers supervised a garden club movement in Holland, which encouraged boys and girls between the ages of ten and eighteen to raise vegetables, keep account of their expenses and profits, and prepare for a special prize contest at the county fair the following year. Holland's youth-led "victory garden" movement was a widespread success. It helped to alleviate pressure on the local agriculture sector during the war, while providing exercise and a wartime purpose for the children. Over the next decade, Rogers also organized Arbor Day tree plantings and other activities for students. Rogers's progressive drive toward mass participation and out-of-doors education led her to propose as a beautification measure the large-scale planting of tulips throughout the city. In a speech before Holland's Women's Literary Club in 1927, Rogers, who was not of Dutch ancestry (in fact she was a Daughter of the American Revolution) and who was not raised in Holland, promoted the tulip as a symbol befitting a festival in the Dutch city. Rogers identified an opportunity for civic growth and tourism. Tulips, after all, were already common in the city; as many as 18,000 had been planted there in 1925. But by combining Dutch cultural themes with the appeal of a flower festival, Rogers envisioned Tulip Time as a rival to the Tournament of Roses in Pasadena. ${ }^{24}$ For Holland to pull off a successful festival, the city would need an incredible number of tulips and unprecedented civic participation. In her speech, Rogers even offered her students' labor for the project. ${ }^{25}$

Non-Dutch Americans such as Rogers, who were amused by the strength of Dutch culture in America, were crucial in organizing the festival during its early years. Ernest Brooks, the New York-born mayor of Holland from 1928 to 
1932, appropriated city funds to order tulips from the Netherlands, and William Connelly, a Holland citizen of Irish descent, led the Chamber of Commerce efforts from 1933 to 1938 to publicize the event. ${ }^{26}$ Much was made of the fact that this leader of a Dutch American festival was of Irish ancestry. In 1934, Holland Sentinel editor Ben Mulder reprinted a line about Tulip Time that had appeared in a newspaper in the Netherlands. "Hollandsche meisjes in 'nationaal' costuum bij het bloemenfest in de Americaansche stad Holland." He wrote, "Connelly, please translate." ${ }^{27}$ Later that season, when the News received a Tulip Time article clipping from a St. Louis German-language newspaper, Mulder lamented that Connelly was unable to read it because of all the gutturals and that the exercise left his throat sore. This kind of ethnic banter was all in good fun. What made these ethnic jokes acceptable was that all those involved were Americans. Like most in 1930s Holland, Connelly was born in America and had American habits. He was as Irish as any third- or fourth-generation Hollander was Dutch, but the ethnic contrast made a good headline. ${ }^{28}$

Yet, as an outsider to Holland and as an American attracted to Dutch culture, Connelly astutely recognized the potential of ethnic tourism. According to the opinions of Holland's elite, William Connelly was Holland's savior during the Great Depression. His strategy for the city addressed three major areas. First, and perhaps most important, he ran public relations for the city and helped make Tulip Time a nationally known event. Next, he got state and national funds involved in local highway construction projects, which aided automobile traffic to the festival. And third, he encouraged industry to move to Holland. By the end of 1936, Connelly's formula "transformed a town badly crippled by depression into one of the busiest industrial centers in Michigan. ${ }^{.29}$ By 1938, twelve new industries had come to Holland, bringing over \$2 million in payrolls and four million hours of labor. ${ }^{30}$

An additional grand proposal for pulling Holland out of the Depression also exploited the city's unique ethnic heritage. Connelly's logic was clear enough. Holland had an increasingly popular ethnic festival. It also had hundreds of men walking the street in search of jobs. Connelly's equation was simple addition. He proposed using welfare workers to clean up the swamp at the mouth of the city's Black River, shaping the land and building an environment that recalled the Netherlands: canals, dikes, windmills, and even Netherlandic houses and barns. The new attraction was to be known as "Klein Nederland." Connelly and his supporters reasoned that Black River was essentially useless as it stood. "Reclaiming" the riverbed would be a massive undertaking, but that is exactly what Holland needed. Initial cost estimates were set at $\$ 600,000$, and Connelly assured the city that the National Relief Agency (NRA) would grant funds for one-third of the cost. The rest of the money the city would have to borrow in loans. The project promised to keep 300 to 400 workers busy for two years, enough time to weather the Depression and begin to reap rewards in tourism. ${ }^{31}$

A skeptical city council first voted 7 to 5 against the project. It was too significant a risk, they said. Some questioned whether the construction of the 
dikes along Black River was even feasible. After all, weren't there sinkholes in the area, and didn't Black River experience spring freshets? In addition, Black River had mosquitoes and was foggy a good deal of the time. The National Relief Agency turned down the project as well. Holland's Johnny Hyma joked, "It looks like NRA funds now stand for 'No River Appropriation." ${ }_{32}$ But the idea of a Klein Nederland and the potential for greater ethnic tourism did not immediately pass away. In September of 1934, the city council voted 11 to 1 for a more modest version of the project. When the mayor cast a veto, stressing his opposition to the $\$ 350,000$ loan the project required, the council still voted 10 to 2, thus overriding the Mayor. Enthusiasm for the project waned, however, and after three months of considering the costs of the plan, the council gradually and reluctantly rescinded the vote. Klein Nederland was no more, but Tulip Time would proceed without it. ${ }^{33}$

While a few politically powerful men such as Connelly and Brooks may have been at the forefront of promoting Tulip Time, local women were primarily responsible for organizing the festival and ensuring its success. Gender roles of the period encouraged women's involvement in civic organizations. The Women's Literary Club, with an overrepresentation of American-born members, often hosted Tulip Show contests at its headquarters. Female klompen (wooden shoe) dancers also drastically outnumbered male dancers and were a large draw. "When they did that Dutch dance, boy people went crazy," remembered a long-time Holland resident in $1995 .{ }^{34}$ When professional newsreel crews documented the dances in 1931, they meticulously noted the names of all ten girl dancers appearing on camera, but failed to record the names of any male dancers. ${ }^{35}$ A 1942 Hollywood film based on Tulip Time, titled Seven Sweethearts, had the protagonist fall in love with the youngest of seven Dutch daughters, only to learn that the elder daughters would have to be married first before he could get the hand of his intended bride. The gendered elements of the Tulip Time Dutch identity were an important part of its national appeal.

To capitalize on this appeal, Dutch Americans through Tulip Time created and marketed new traditions. In 1983, Eric Hobsbawm made the important observation that some cultural practices or traditions are not genuinely traditional, but that they can be invented to serve ideological ends. Hobsbawm's concept, "the invention of tradition" (also the title of his book), quickly gained currency in social science scholarship. Three years after Hobsbawm's book was published, [Werner Sollors, The Invention of Ethnicity] built on the theme of invention to assert that ethnicity, too, is invented. Ethnicity is not "invented" in the sense that it appears out of thin air or is superficial, but it is invented in the sense that it is a dynamic categorization, often shaped to satisfy a desire for collective

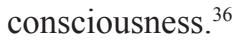

The early-invented stereotypes and mischaracterizations of traditional Dutch culture arising from Tulip Time were the result of a failure to adequately study Dutch culture. The touristic appeal of the festival, and its success, depended, however, on its ability to present "authentic" images of the Dutch. The 
promoters of the festival from the 1940s forward therefore attempted as much as possible to authentically represent the culture of the Netherlands. Willard Wichers, director of the city's museum, was often called upon for his advice about Dutch culture. But their zeal to satisfy tourists and their own ethnic longing caused Hollanders to invent new traditions where old ones would not suffice. Tulip Time was not Dutch tradition per se, but a tradition built on Dutch themes. Therefore, when the costumed klompen dancers learned to shuffle in their wooden shoes, they were not learning a Dutch tradition but rather a Tulip Time tradition. Schoolteacher and early participant in Tulip Time, Margaret Van Vyven, recalled that "We taught Tulip Time in all the elementary schools." 37 Van Vyven was right: Tulip Time had to be taught. The lessons had to be written before they could be learned.

Those who had never been to the Netherlands could be easily confused as to the nature of Dutch culture, since the festival displayed multiple views of "Dutchness." Some hoped to represent the seventeenth-century Dutch Golden Age, when business and arts flourished in the Netherlands. Thus, the city council could be seen on the streets, as one observer noted, "looking for all the world as if they had just stepped out of a Rembrandt canvas." ${ }^{138}$ Ridiculing the situation, alderman Peter Huyser thought "that, rather than make council members look like native Netherlanders, the gowns worn by the 'city fathers' made them look like "clowns." ${ }^{39}$ Representations of the Dutch also drew on the popular turn-of-the-century American art-based stereotypes of the Dutch, an interest labeled "Holland Mania" by art historian Annette Stott. During Holland Mania, American artists portrayed the Dutch as quaint relics of the Golden Age, akin to figures from the paintings of Rembrandt, Vermeer, and Hals. ${ }^{40}$ Artists also favored the image of the pipe-smoking little Dutchman or the Dutch child with a speech impediment (like the Germans, he could not pronounce a W), images that were accepted for their stereotypical simplicity and their easy employ in paint-by-number postcard images. Text on cartoon postcards, for example, replaced W with V to ridicule Dutch or German speech. An example would be "Ve Vish you a Merry Christmas." Holland Mania themes in Tulip Time were common and included an emphasis on the dress of the fishing town of Volendam, a sort of nonindustrialized romantic relic of a bygone era. Despite its poor representation of the Netherlands as a whole, the Volendam costume was and has remained a dominant image of Tulip Time. Such popular images proved commercially successful. "The tourists eat up the propaganda as readily as the food," wrote Arnold Mulder. ${ }^{41}$ Despite the inaccuracies, the citizens of Holland who were of Dutch ancestry "ate it up" too.

The city of Holland and its Tulip Time organizers were preoccupied with marketing the festival as an authentic representation of Dutch culture. The new ethnic identity was shaped by the promotion of authenticity for an American audience willing to pay. "More than one visitor was heard to remark that the chief charm of the festival is the note of authenticity that runs through the whole affair," wrote a correspondent for the Grand Rapids Herald in $1937 .{ }^{42}$ The editor 
of the Chesapeake and Ohio Pere Marquette Magazine, a publication of a railroad that would stand to gain from the transportation of visitors to the festival, wrote in 1938 that Tulip Time was successful because of "its adherence to the authentic" and lack of "commercialism, ballyhoo and carnival." had been seen before. "Holland's festival is devoid of commercialism," the editor of the Holland City News wrote in 1936. "There is nothing tawdry or low about the spectacle. All ballyhoo and sideshow features are simply not a part of Tulip Time."

On the one hand, the writers were correct: Tulip Time in the 1930s was different from some rowdy American festivals. It was wholesome and family oriented with no outside vendors or circus atmosphere. But to say that the festival had "no taint of commercialization," as did the Studebaker Wheel Magazine in 1937, was either an uninformed or an intentional mischaracterization. ${ }^{44}$ In 1936, Tulip Time added a Dutch marionette show and a well-researched miniature model of a Dutch village, known as Little Netherlands. "Folk like changes and we must have money," the local newspaper reported. "These new attractions were the saving grace of the festival's strong box." ${ }^{45}$

Authenticity was important in name, but not always in deed. Newspaper advertisements during Tulip Time took advantage of Dutch themes. One could find Dutch Kraft varnish with a windmill image or other similar images of products marketed with tulips or wooden shoes. Holland Furnace Company, the largest financial contributor to the festival, hoped that the novelty of the Holland name would help in sales. Through its employees and sales force around the country, the company marketed the old country warmth of its "Warm Friend" furnace. ${ }^{46}$ Dutch Americans contributed to an idealized Tulip Time version of their ethnic group. The Holland Sentinel carried the lines that at Tulip Time, the "sun shines as bright as the golden hair of the dancing maidens, and skies are as blue as the breeches of the clattering Dutchman." $" 47$

Costumes, in particular, were essential in establishing the authentic atmosphere of the festival. In 1953, Esther Veen Huis, a native of Kalamazoo, Michigan, finished a home economics master's thesis on the costumes worn by the Tulip Time klompen dancers. Veen Huis's study was primarily concerned with the fabrics of the costumes and their material authenticity. According to Veen Huis, the costumes during the early years of the festival were not authentic and were just layered blue and white fabrics based on images from Delftware pottery. In essence, these patterns were a perpetuation of Holland Mania themes. "This was a popular but unfortunate conception of Dutch coloring," Veen Huis related. Yet, Veen Huis was proud of how far the costume designs had come in the following decades. She had been involved in the festival since the late 1930s and could attest to the progress made in authentic costuming. The female dancers who were responsible for buying fabric and sewing their own costumes now had to "pass rigid inspection" to verify the authenticity of their dress. The goal of Veen Huis's study was to introduce to the festival another "authentic" costume to give the girls more options for costuming. ${ }^{48}$ 
While Esther Veen Huis's intentions were good, her information was not necessarily reliable. Veen Huis's parents had migrated from the Netherlands to West Michigan in the late nineteenth century, but they had arrived in their youths: her father was seventeen and her mother just nine upon entering the United States, so their memories of traditional Dutch attire might not have been very vivid. Furthermore, as the sixth of a couple's six children and educated in American schools, Esther required translation assistance for her study, so it is likely that she lacked or had only a rudimentary education in the Dutch language. Rather than authenticity, her primary criteria for selecting a new costume were aesthetics and function. In designing a new costume for the festival, Veen Huis settled on a blue/purple/orange pattern from the Dutch Island of Urk. She introduced the costume "to make the dance even more colorful and interesting." ${ }^{49}$ The costume also had to be flexible enough to dance in, lightweight, and not likely to shift too much while worn. Her design was accepted by the organizers of Tulip Time and worn by ten girls in the 1951 festival.

As authentic as the costumes may have been materially, they were not representative of the provenance of the Dutch American immigrants, few of whom, if any, actually hailed from Volendam, Marken, or Urk. Thus, traditions from a few isolated villages in the Netherlands were used to represent the traditional dress of the entire nation. ${ }^{50}$ Also, Veen Huis mistakenly referred to the costumes as provincial, when in fact they were native to specific villages and not provinces more generally. Moreover, the costumes were, of course, not contemporary, but based on paintings and images from the nineteenth century or earlier. Harry Hoekstra, a first-generation immigrant from the Netherlands recalled the irony of his experience as a volunteer in the festival the 1940s. "One of the funny things was that I thought that they didn't want me to participate unless I had a Dutch costume, and so I had to come from the Netherlands to America, before ever I wore a Dutch costume." ${ }^{.51}$ This was the new authenticity.

Because of the demand for authenticity, some first-generation Dutch American immigrants saw the festival as an opportunity to exploit their status as "truly Dutch." For example, a first-generation immigrant might express interest in recovering ethnicity by altering a Tulip Time tradition to bring it more into line with his or her memory of a tradition in the Netherlands. Or he or she might introduce a new tradition altogether. In the 1930s, for example, tulip plantings were under the direction of Jan Van Bragt, a first-generation immigrant who learned from his father in the Netherlands the "proper" way to plant a tulip. ${ }^{52}$ Dutch-born Peter Buis, who had recently returned from a trip to the Netherlands, was able to verify the accuracy of Holland's painstakingly constructed model of "Little Netherlands." ${ }^{53}$ Likewise, Jennie Van Eerden, who had grown up in the province of Zeeland, influenced the development of the "street scrubbing" tradition by providing the participants with her memory of the chore. Street scrubbing was introduced in the 1931 festival, and like the klompen dancing, it too was recorded for newsreels. Van Eerden wanted to make sure the street scrubbers behaved in an authentic manner. The key to cleaning the streets in the "old 
country," she taught, was to bend over with the broom but not to rest on hands and knees. While Van Eerden's advice about technique may have been rooted in real tradition, the use of Dutch Cleanser, a popular American household cleaning product picturing a fastidious Dutch woman, most definitely was not. The cleanser left a soapy residue on the streets and was never used in street scrubbing again after its appearance in 1931, although street scrubbing continued to be a popular Tulip Time tradition. The act of drenching fellow participants with a bucket of water was an added tradition. ${ }^{54}$ Ideas that began with some level of authenticity sooner or later evolved into new Dutch American traditions.

First-generation immigrants were in highest demand, however, not for advice on traditions, but for their ability to speak Dutch. According to linguist Peter Veltman, the chance that one might hear the Dutch language was one of the primary tourist attractions of Tulip Time. ${ }^{55}$ Holland advertised that coming to Tulip Time was like visiting a piece of Europe in the United States. In one particular instance, a family from the Netherlands took advantage of the newfound interest in the Dutch and toured the breadth of the United States, dressed in Dutch garb, riddling off Dutch proverbs, and selling Dutch novelties along the way to pay for the trip. ${ }^{56}$ With the introduction in 1941 of the position of "town crier," first played by first-generation immigrant Clarence Jalving, visitors were more likely to hear the foreign Dutch language. The position of town crier, it was explained, was "reminiscent of the old days when the communications in the Netherlands were less modern." The town crier's main duty was to walk the streets and declare in the Dutch language the opening of the festival. ${ }^{57}$

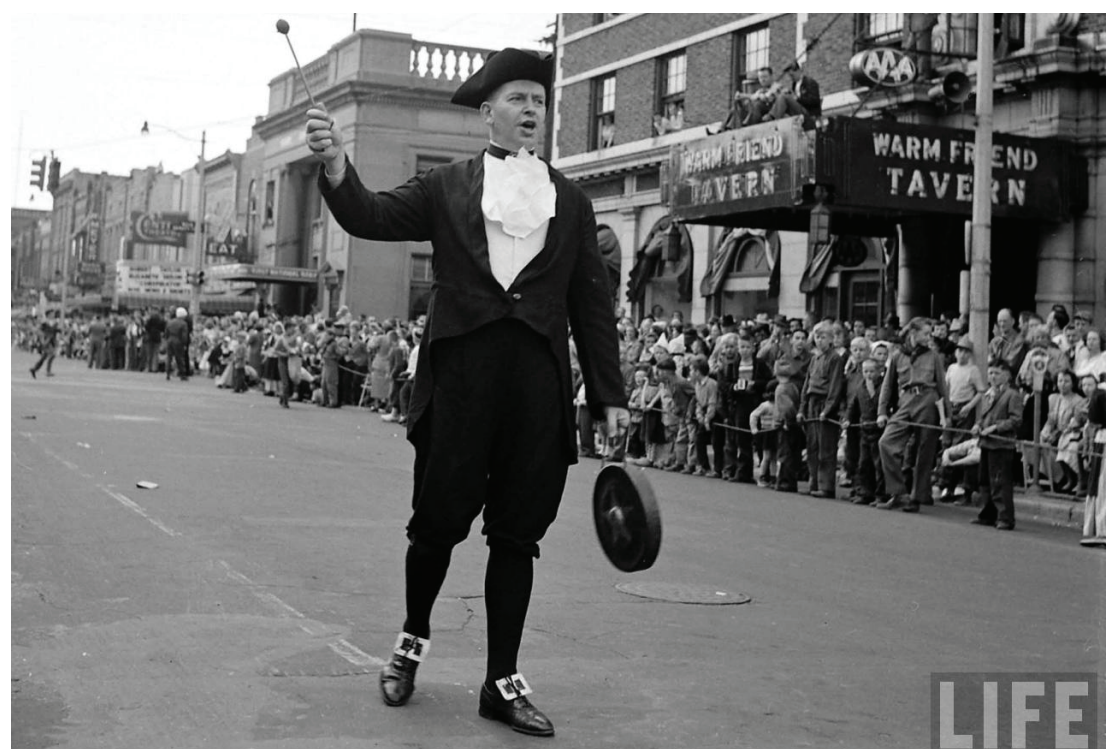

Figure 2: Town crier with a hand bell. Photographs of Holland, Michigan's Tulip Time parade taken for Life Magazine, May, 1950. Photograph by George Skadding. 
In Dirk Gringhuis's fictional children's story, Tulip Time, published in 1951, readers learn that language denotes authenticity. The story begins one day in May when a maker of wooden shoes, the unsophisticated old immigrant "Uncle Klaas," steers his equally out-of-date car to Tulip Time, bringing along his curious nephew and niece, Gerrit and Greta. At the festival, Gerrit laughs amusedly at the street scrubbers, but Greta is stern-faced, concerned because as the children are caught up in the crowds, they become separated from their uncle. When Gerrit spots Uncle Klaas in the parade, the children are amazed to learn that their Uncle Klaas is the town crier. "You didn't know your old uncle was Town Crier, did you?" Klaas later asks the children. When the children visit the Netherlands Museum, Klaas points out the recognizable artifacts from the old country. The story ends when the children, who have entered a flower arrangement in the Tulip Show, win first prize. Their display consists of a small garden planted in a wooden shoe with a picture of their Uncle Klaas. The children whisper to Uncle Klaas "Now everyone will remember you."

Gringhuis's story explains the various roles Dutch Americans played in Tulip Time. The old immigrant Klaas is eager to show off his Dutch culture, while the immigrant children who have been raised in the American culture

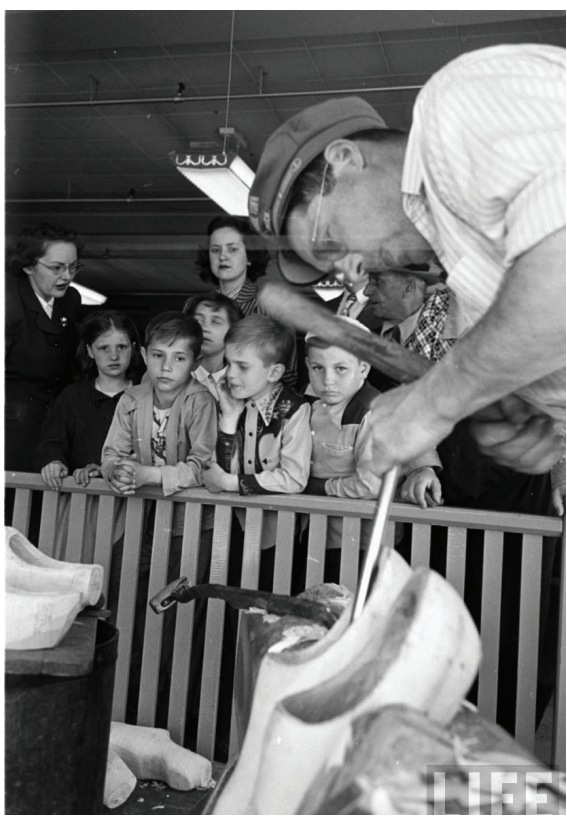

Figure 3: A Tulip Time shoemaker, like Gringhuis's fictional "Uncle Klaas." Photographs of Holland, Michigan's Tulip Time parade taken for Life Magazine, May, 1950. Photograph by George Skadding. are interested in learning about their heritage. Curiously, the children's parents, perhaps not as interested in their heritage, are mostly absent. That Uncle Klaas no longer has any customers at his wooden shoe shop is also indicative of the declining interest among immigrants for the traditional Dutch culture. But the young children are captivated by what they learn about the Dutch at Tulip Time and they want everyone to remember Uncle Klaas.

After 1957, visitors of Holland, Michigan, could experience a bit of Tulip Time year-round. In 1957, Harry Nelis opened a Dutch souvenir shop near the highway in Holland Township, hoping to profit from the tourist traffic and direct people to the festival. In 1965, the tourist shop was replaced by "Dutch Village," a collection of buildings and bridges that imitated a scene from the Netherlands. The village grew in the 1970s. ${ }^{59}$ From 1960 to 
1999, the Nelis family also operated the Dutch-themed "Queen's Inn" restaurant on the property. ${ }^{60}$ Like the organizers of Tulip Time, Dutch Village sought the elusive "authenticity" that would draw visitors. Netherlands-born Swenna Harger began working at Dutch Village in the summer of 1972 and was called upon to help decorate the property's Dutch farmhouse in a style that met her sense of authenticity ${ }^{61}$ Dutch Village remains one of the enduring symbols of Dutch American ethnic identity.

When Tulip Time began, none intended it to establish a new Dutch American ethnic identity, but the festival's success allowed it to do just that. With the advent of automobile culture and the shortages of the Depression, Holland could market itself as a European destination within financial and geographical reach of the average Midwestern American. The new Tulip Time image of Dutch America was influenced and promoted for financial gain, both individual and civic. An oral history project conducted in Holland in 1995 recorded the memories of a number of those who as children participated in the festival in the 1930s. When asked about the early years of Tulip Time, they recalled a sense of excitement, fun, and, notably, opportunity. One memory in particular is illustrative of how Dutch themes, regardless of their progeny, could be used for financial advantage, even by those who were not first-generation immigrants. Hattie Grisgy remembered two childhood friends who dressed up exactly like the children pictured on the package of Holland Rusk (a type of Dutch biscuit). "[T] hose kids could go out and make more money at Tulip Time. Everybody'd give you a dime or a quarter or fifty cents or a dollar to have your picture taken." ${ }^{62}$ Because it was easy to profit from the invention of this new Dutch American hybrid identity, the Tulip Time images of Dutch Americans were propagated near and far.

Holland, Michigan's, Tulip Time festival was a forum for the invention and expression of traditions developed and maintained by all stripes of individuals. Although some Dutch American immigrants turned up their noses at displays of Dutch heritage, by the 1930s, acceptance and promotion of this new cultural representation became a dominant force in the Dutch American community. With the organizational help of non-Dutch Americans, and fueled by the desire to appease thousands of tourists, Dutch Americans from various generations approximated the pattern described in Hansen's principle of third-generation interest. First-generation immigrants from the Netherlands added their own correcting "expertise" to the festival and enjoyed the special status and attention provided by thousands of Tulip Time visitors. Economic incentives allowed the new image of Tulip Time to flourish. Gone were the days of the nineteenthcentury Dutch immigrants, those pious folk whom the novelist Arnold Mulder had described as wearing plain dark clothes and reciting Bible verses as they passed each other on the streets. The new image of Dutch America was much more colorful, quaint, and commercial. It has had a lasting impact on Dutch American identity. 


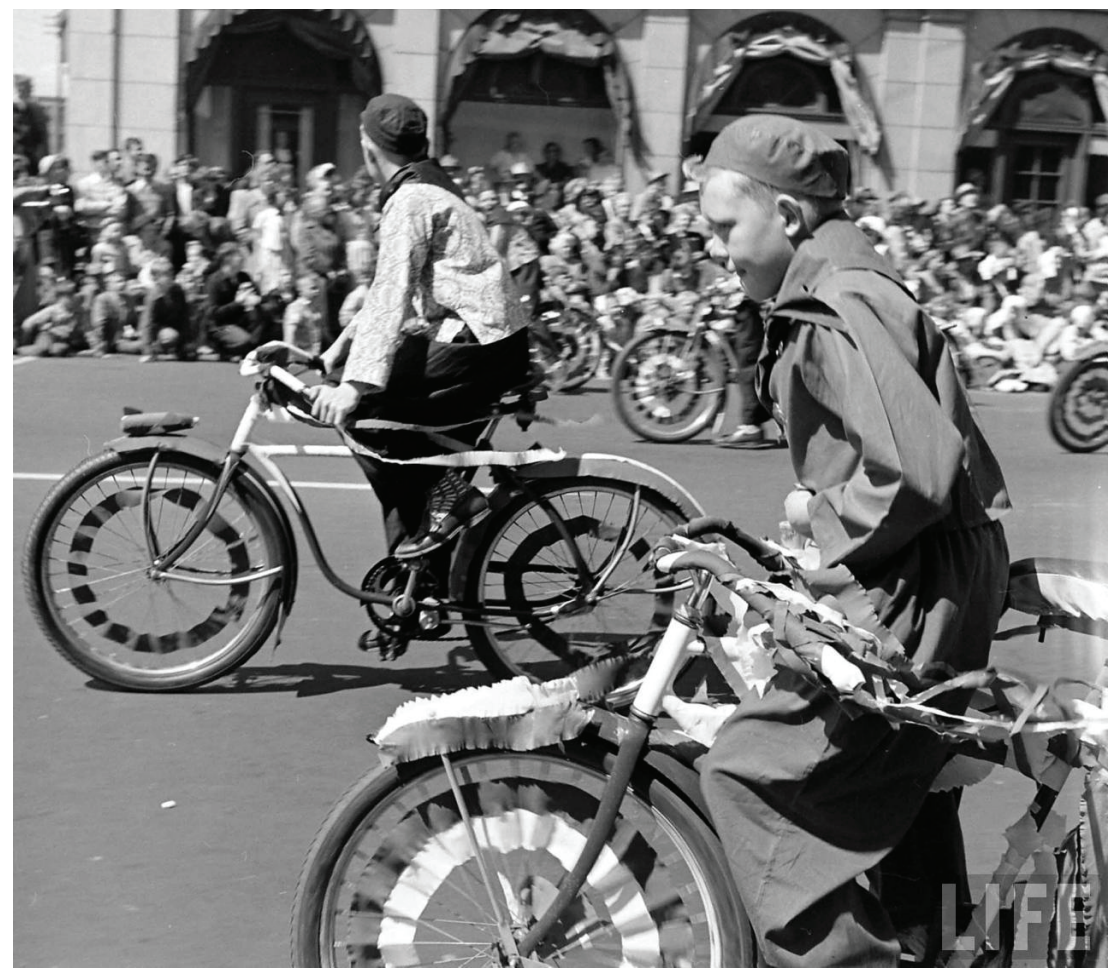

Figure 4: Boys with emblazened bikes peddle in the well-attended parade. Photographs of Holland, Michigan's Tulip Time parade taken for Life Magazine, May, 1950. Photograph by George Skadding.

The secularization of Dutch American identity through Tulip Time also popularized it. What used to be an isolated, insular Dutch American identity now opened itself up for the world to view. Isolation was seen as quaintness. The festival was an adaptable and marketable product that spread to other settlements of descendants of Dutch immigrants. In Iowa, Pella and Orange City began their own festivals in 1935 and 1936, respectively. Other Dutch heritage festivals, such as Fulton, Illinois', Dutch Days and Edgerton, Minnesota's, Dutch Festival incorporated themes appropriated from the original Tulip Time..$^{63}$ Additional Dutch heritage festivals were organized in Cedar Grove, Wisconsin (1947); Albany, New York (1949); Clymer, New York (1953); Redlands, California (1953); Holland, New York (1954); Oak Harbor, Washington (1969); Nederland, Texas (1973); Little Chute, Wisconsin (1982); Denver, Colorado (1982); Baldwin, Wisconsin (1983); Hempstead, New York (1983); Lynden, Washington (1986); Wamego, Kansas (1987); and Palos Heights, Illinois (1996) ${ }^{64}$ These festivals typically serve Dutch food, invite politicians and Dutch royalty, and promote history and heritage. Dutch "authenticity" con- 
tinues to be an important theme of the festivals. The words of the Pella, Iowa, Tulip Queen of 1979, Mindy Roozeboom, illustrate this fact. "I wasn't the only pretty girl, and I wasn't the only girl with poise. But we each had to give a little talk about our most unforgettable experience. I told about my grandmother, who was a very valiant woman. She was a diabetic, and when I was just starting high school she had to have her leg amputated. But she didn't give up. She had herself fitted with an artificial leg, and she was walking in no time. They say the Dutch are determined. Well, my grandmother was very Dutch. She used to say 'You can do it if you try.' So I told about her, and when I came to her motto, I said it the way she used to say it, in Dutch: 'Je kan het wel als je wil.' I think that appealed to the judges." ${ }^{65}$

\section{Notes}

1. The Holland Sentinel, May 27, 1937, estimated a record 750,000 visitors at that year's festival. This was likely the peak year in the festival's history. $87-88$.

2. Arnold Mulder, "A Special Stake in the War," Common Ground 3, no. 2 (Winter 1943):

3. Suzanne Sinke, "Tulips Are Blooming in Holland, Michigan: Analysis of a DutchAmerican Festival," in Immigration and Ethnicity: American Society- "Melting Pot" or "Salad Bowl," ed. Michael D'Innocenzo and Josef P. Sirefman (Westport, CT: Greenwood Press, 1992), $3-14$.

4. Marcus Lee Hansen, "The Problem of the Third Generation Immigrant" (delivered to the Augustana History Society, Rock Island, IL., May 15, 1937] in American Immigrants and Their Generations: Studies and Commentaries on the Hansen Thesis After Fifty Years, ed. Peter Kivisto and Dag Blank (Chicago and Urbana: University of Illinois Press, 1990), 191-203.

5. See articles by Nathan Glazer, H. Arnold Barton, and Thomas J. Archdeacon in Kivisto and Blank, American Immigrants. Empirical studies show that the "third generation recovery" model fits some American immigrant groups (Jewish, Swedish, Scottish, etc.) better than others (Polish, Italian). Eugene I. Bender and George Kagiwada, "Hansen's Law of 'Third-Generation Return' and the Study of American Religio-Ethnic Groups," Phylon Vol. 29, no. 4 (4th Qtr., 1968), $360-70$.

6. For example, in the 1960s the Swiss in New Glarus, Wisconsin, created new forms of ethnic identity to lure tourists into their local shops. Steven D. Hoelscher, Heritage on Stage: The Invention of Ethnic Place in America's Little Switzeland (Madison: University of Wisconsin Press, 1998). Other examples include Carolyn E. Ware, "Marketing Mardi Gras: 'Heritage Tourism in Rural Acadiana,"” Western Folklore 62, no. 3 (Summer, 2003): 157-87.

7. Leonard Dinnerstein and David Reimers, Ethnic Americans: A History of Immigration, 5th ed. (New York: Columbia University Press, 2009), 182.

8. Deborah Che, "Reinventing Tulip Time: Diasporic Dutch Heritage Celebration in Holland (Michigan)," in Tourism, Diasporas and Space, ed. Tim Coles and Dallen J. Timothy (New York: Routledge, 2004), 261.

9. Ibid.

10. Peter Moerdyke, "The Story of Tulip Time," Collection 0132, Peter Moerdyke Papers, Holland Michigan Museum Archives, Holland, MI.

11. Kathleen Neils Conzen, "Ethnicity as Festive Culture: Nineteenth-Century German America on Parade," in The Invention of Ethnicity, ed. Werner Sollors (New York: Oxford University Press, 1989), 44-76. The associational world of Germans in America and their distinctiveness as an ethnic group declined after 1890, however, and as Russell Kazal has argued, Germans in early twentieth-century America consciously worked to identify as "old stock" Americans. Russell A. Kazal, Becoming Old Stock: The Paradox of German-American Identity (Princeton, NJ: Princeton University Press, 2004).

12. April R. Schultz, Ethnicity on Parade: Inventing the Norwegian American through Celebration (Amherst: University of Massachusetts Press, 1994), 9.

13. Larry Danielson, "St. Lucia in Lindsborg, Kansas," in Creative Ethnicity: Symbols and Strategies of Contemporary Ethnic Life, ed. Stephen Stern and John Allan Cicala (Logan: Utah State University Press, 1991), 187-203.

14. Lon Kurashige, Japanese American Celebration and Conflict: A History of Ethnic Identity and Festival in Los Angeles, 1934-1990 (Berkeley and Los Angeles: University of California Press, 2002), xiv. 
15. Ibid., v.

16. While the majority of Dutch immigrants to America were Protestant, there were also substantial numbers of Dutch Catholic, Jewish, and nonreligious immigrants. These later groups, however, appear to have been less cohesive. For examples see Yda Schreuder, Catholic Immigrant Settlement in Wisconsin, 1850-1905 (New York: Garland, 1989) and Robert P. Swierenga, The Forerunners: Dutch Jewry in the North American Diaspora (Detroit, MI: Wayne State University Press, 1994).

17. Jacob Van Hinte, Netherlanders in America: A Study of Emigration and Settlement in the Nineteenth and Twentieth Centuries of America, ed. Robert P. Swierenga, trans. Adriaan de Wit (Grand Rapids, MI: Baker Book House, 1985; Groningen: Noordhoff, 1927).

18. Ibid., 981, 988 .

19. Ibid., 1015.

20. Herbert Brinks, "Impressions of the 'Old World': 1848-1940," in The Dutch in NorthAmerican: Their Immigration and Cultural Continuity, ed. Rob Kroes and Henk-Otto Neuschafer (Free University of Amsterdam Press, 1991), 35-47.

21. Arnold Mulder, Americans from Holland (Philadelphia, PA: J. B. Lippincott, 1947), 289.

22. Ibid.

23. Nieuwe Leidsche Courant, March 29, 1949. Translation of "Klompen en Volendammerkleren en jukken met emmers water en dan worden de straten geboend. En uit Hollywood komen de filmsterren om zich te later fotografen met een bezem in de hand. 'Het is aardig, om te zien, maar het is allemaal publiciteits-onzin. I don't like it."'

24. Holland City News, March 11, 1925.

25. Holland City News, March 18, 1918, Collection T89-1032, Lida Rogers Papers, Holland, Michigan Museum Archives, Holland, MI. Mulder, "Special Stake," 88.

26. Peter Moerdyke, "The Story of Tulip Time," 1939.

27. Holland City News, April, 12, 1934.

28. Holland City News, April 5, 1934; May 17, 1934; Oct. 17, 1935; March 24, 1938.

29. Holland City News, Dec. 3, 1936.

30. Holland City News, Nov. 19, 1936; July 28, 1938.

31. Holland City News, Aug. 17, 1933.

32. Holland City News, Aug. 24, 1933; Aug. 31, 1933.

33. Holland City News, Sept. 28, 1933; Feb. 8, 1934.

34. The quote is from a participant named only "Mrs. Bonenberg" in an oral history interview of Hattie Grisgy Grigsby, June 2, 1995, Collection H88-0234, Joint Archives of Holland, Michigan, and Hope College Living Heritage Oral History Project, 1995. The archives of Hope College are found within the Joint Archives of Holland, an archive established in 1988 to maintain collections of the college, Western Theological Seminary, and the city of Holland, Michigan.

35. Randall VandeWater, Holland Happenings 1 (1994), 54. In a 1995 oral history interview, Jack Leenhouts of Holland claimed that there were few male Dutch dancers at first because the conservative Dutch disapproved of boys and girls dancing together. Collection H88-0234, Joint Archives of Holland, Michigan, and Hope College Living Heritage Oral History Project, 1995.

36. Eric Hobsbawn and Terry Ranger, The Invention of Tradition (New York: Cambridge University Press, 1983); Werner Sollors, ed. The Invention of Ethnicity (New York: Oxford University Press, 1989).

37. Oral history interview of Margaret Van Vyven, June 21, 1995. JAH, H88-0234, Hope College Living Heritage Oral History Project, 1995.

38. Peter Moerdyke, "The Story of Tulip Time," 1939.

39. Holland City News, May 19, 1938.

40. Annette Stott, Holland Mania: The Unknown Dutch Period in American Culture and Art (Woodstock, NY: Overlook Press, 1998).

41. Mulder, Americans from Holland, 287.

42. Holland City News, May 27, 1937. Reprint of article from Grand Rapids Herald.

43. Holland City News, May 12, 1938. Reprint of article from Chesapeake and Ohio Pere Marquette Magazine.

44. Holland City News, May 13, 1937. Reprint of article from Studebaker Wheel Magazine.

45. Holland City News, May 14, 1936.

46. Holland City News, May 13, 1997.

47. Holland City News, May 18, 1939. Reprinted from Grand Rapids Herald.

48. Esther Veen Huis, "Historic Dutch Provincial Costume Adapted to Klompen Dancers of the Tulip Festival in Holland, Michigan" (master's thesis, Colorado Agricultural and Mechanical College [now Colorado State University, original held at the Sage Library at CSU], 1953), 33, 34.

49. Ibid., 143.

50. Ibid.

51. Oral History Interview, Harry Hoekstra, June 28, 1995, JAH, H88-0234, Hope College Living Heritage Oral History Project. 
52. Moerdyke, "The Story of Tulip Time," 1939.

53. Holland City News, May 19, 1938.

54. Randall Vandewater, "Street Cleaning Started as Stunt," Holland Sentinel, October 19, 2003.

55. Peter Veltman, "Dutch Survivals in Holland, Michigan," American Speech 15, no. 1 (1940), 80-83.

56. Holland City News, May 13, 1937.

57. Holland City News, May 14, 1941.

58. Dirk Gringhuis, Tulip Time (Chicago: Albert Whitman \& Company, 1951).

59. Mike Lozon, "Dutch Village Remains Big Attraction in Hub of Retail," Holland Sentinel, October 26, 1997.

60. Mark Sanchez, "Village Now the Focus with Queen's Inn Closed," Holland Sentinel, October 24, 1999. 20, 2008 .

61. Myron Kukla, "Nelis' Dutch Village Celebrating 50 Years," Grand Rapids Press, April

62. Grisgy, interview.

63. Terrence Schoone-Jongen, The Dutch American Identity: Staging Memory and Ethnicity in Community Celebrations (Albany, NY: Cambria Press, 2008).

64. Janet Sjaarda-Sheeres, "Klompen Dancing through America," in Papers of the Association for the Advancement of Dutch American Studies: 12th Biennial Conference, Dutch Enterprise: Alive and Well in North America (1999), 71-82. The papers from this conference were edited by Larry J. Wagenaar and Robert P. Swierenga, were copyrighted by the Joint Archives of Holland, which printed the proceedings on a regular office printer.

65. Berton Roueche, "Profiles (Pella, Iowa)" The New Yorker, December 24, 1979, 46-48, quote on 63. 
